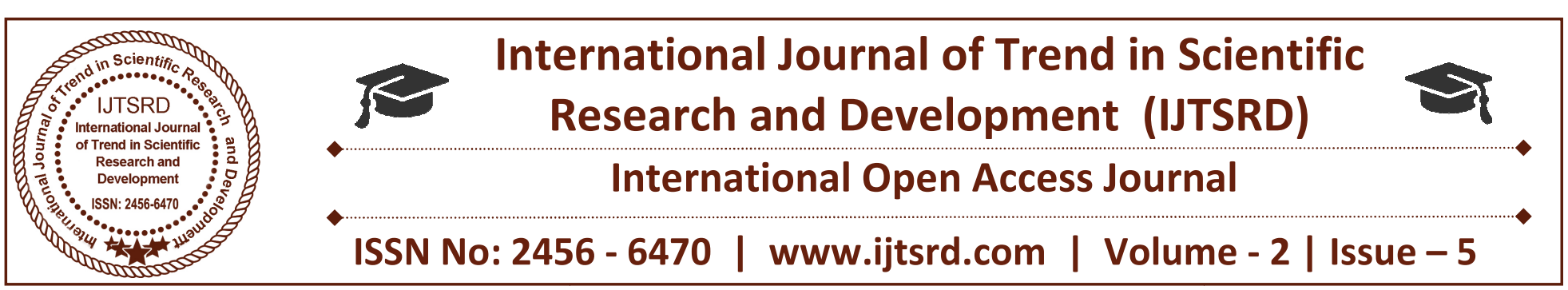

\title{
Poverty and Child Labour Need to Reduce Access to Education Development in Uttar Pradesh
}

\author{
Ram Gopal \\ Research Scholar, University of Lucknow, Lucknow, \\ Uttar Pradesh, India
}

\begin{abstract}
Child labour is a world -wide phenomena, any child out of school is a child labour. Child labour is the cause of absolute poverty. Child is working to long hour's bad unhygienic condition with low wage. Child labour very serious problem in Uttar Pradesh. Child labour have available in rural in urban area both. Child labour needs to reduce by the access of education. Human capital is very necessary any country development. UNICEF work for child development and protection as well as provide to education under the all children right to education whole world's children.
\end{abstract}

Key Word: Child, Uttar Pradesh, Poverty, Education, Labour

\section{INTRODUCTION}

Child labor is a world- wide phenomena, any child out of school is a child labor. Most of the child labors are engaged in agriculture and allied subject- like livestock, foresting and fisheries. In urban area, child work in dhabas, enterer helps as a trucks and domestic service. Access to other work by children manual base industries such as bricks fields, carpet industry, others. Children have to work long hours in bad and unhygienic conditions with low wage. Strong fundamental "early childhood care and education"Almost all out-of-school children are in India and state of Uttar Pradesh compare to other major state of India. Child labor is very serious problem in State of Uttar Pradesh. Child labor is working to out of poverty. Human capital (education health and motivation) has always been an extremely important determinant of individual social progress. It is important increases competitive knowledge- intensive global economy (Marshall-2005). The rate of

economic growth is crucially depends on the stock of human capital in a country (Romer 1987; Lucas 1988; Barro 1991; Mankin 1992; Todaro and Smith, 2009) eliminating poverty in developing countries (Ersado2002) and give rise to socio-economic problem. Lowlevel human capital development affected children's future in form of directly or indirectly. So children are an asset for a nation (Tripathy, 1994, Mehta, 2008). Every child who is out of school or participating in labor force for the sake of family support conflicts directly or indirectly with its natural growth and education which are prevent him/her from attending proper adulthood and training (Chander; 2004). So, if we take human capital of human capacity prospective (as given by Sen,2000), the incidence of working children any society leads to lower human capacity which means enormous less to the economy. The incidence of child labor is low and level of education high. The children are who labor at, tasks that harm their bodies and minds, their spirits and future UNICEF (2001). India is one of the main users of child labor in ASIAN region (Singh, 2003). The level of family income is determining the role of children in economic activities. Poverty is main factor behind child work (Bequele and Boyden, 1988, Jain,1994, Grootaret and Kanbur, 1995). Children work even in unjust conditions when the income of their family is not sufficient to meet the basic requirement of the family (Fors, 2008). The International Labor Organization (ILO) and UNICEF defines, "Child labor as work that deprives children of their childhood and their dignity which hampers their access to education and the acquisition of skills and which is performed under deplorable conditions harmful to their health and developed" (ILO/UNICEF, 1997). 


\section{Methodology and data:}

Analysis the descriptive and secondary data use NSSO and Census different decadal years' government of India such as 1991, 2001 and 2011 census. The conceptual and descriptive analysis is use of ILO and UNICEF framework, child labor in Uttar Pradesh. Rural and urban domestic and agriculture, manual other work by child labor in Uttar Pradesh.

\subsection{Objective of Studies}

1. Status of child labor in Uttar Pradesh,

2. Qualitative education importance for child labor descriptive analysis,

3. Poverty and child labour.

4. Rural and Urban child labour analysis

5. Historical and constitutional review and rule,

\subsection{Historical background of child labour}

The child labor is depending on the existing socioeconomic structure of society. It is saddening to note that India is the largest employer of child labor.

\section{The child labor in Ancient India:}

The child labor in ancient India could not denied because the slaves of tender age were born as slaves unless the master was not pleased to monument them. In ancient India, child slaves had sold and purchase like as commodities. There was violation of child right from the ancient time also. The duty of king to educate every girls and boys where parent had punished for not sending to school called Ashrams. Grukul education system could not be assessing as child in modern sense because Gurukul education system was a residential by staying at guru's home and help him in day today life and earned their way by contributing their labor to the operation and maintenance of the school. Several indication meet to related child exploitation from ancient texts of Arthashastra of Kautliya. During the fourth century B.C., Kautilya also prohibited to sale and purchase of slave children below the eight year of age.

\section{Child Labor in Medieval Period:}

The medieval period had also hunted the minds of many schools reform. A class of landless labors came into existence, It was introducing to traditional craft at a young age. The children were engaging as trainees under the guidance of their parents. They were sold by their parents, because need of economic necessity. The child labor in medieval India was quite aggressive and rulers turned a deaf- ear to the problem of child exploitation. They turned money at the change of the children work.

\section{Child Labor in Modern India:}

During the modern period, British rule and toward Indian education can be evaluated from the recommendations of Charter-1813, by which British Viceroy's desire to develop a cream of literate masses which could be India is blood and English is test. The child labor underwent a dynamic change in British India. The capitalism system destroyed the family base economy and a large number of labors had displaced due to mechanism of agriculture, industrialization changes to socio-economic order.

\subsection{Constitutional Provision of Child labour}

The government of India has taken certain initiatives to control to menace of child labor in India. The constitution of provision, many laws and policies are labor made for proper growth and development of children from exploitations and elimination of child labor from the country.

\section{Article -24:}

No child below the age 14 years shall have employed to work in any factory or work which is hazardous.

\section{Article- 39(E):}

The state shall direct its policy towards securing the health and strength of workers, men and women and the tender age of children have not abused.

\section{Article- 39(F):}

Children shall have given opportunities and facilities to develop in a healthy manner and in conditions of freedom and dignity.

\section{Article- 45:}

The state shall endeavor to provide within a period of Ten year from the commencement of the constitution for free and compulsory education for children until they complete the age of 14 years.

\section{Article-243(G):}

Provides for institutionalization of child cared by seeking to entrust programs of women and child development

$>$ The implementation of right to education acts of 2010 ensures free and compulsory education for children between the age of 6-14 years.

The child Labor-Prohibition and Regulation Act1986 - defines "Child as labor who has not 
completed his fourteen years of age, whatever part-time/full time in any occupation engagement of child in the labor force simply mean a competes or partial denial of childhood to him"(Government of India-1986).

The most significant among than were the National Commission and child labor (19661969), The Gurupadaswamy committee on child labor (1979) and the Sant Mehta Committee (1984).

There most important judicial intervention in the action against child labor in India. India was M.C Mehta case (1996) in which Supreme Court, directed the union and the state governments to identified all children all working in hazard process and occupations to with them from work, and provide to good quality of education. India under the ILO's IPEC is covering more than 90,000 thousand children with direct funding by the ILO office to NGO's.

According to the Article-3(D) of International Labor Organization convention 182, hazardous work referred as "work that by its nature or the circumstances in which it is carried out, is likely to harm the health safety and morals of children" (ILO, 2011).
The Promotion are positive social and cultural ideal attitudes traditions, behaviours and practices, which are essential to address issues such as gender, child labour, and other protection concerns.

$>$ The creating an atmosphere of open and innocent discussion on child protection, including engagement with the media and civil society to raise and address child protection concern; building children's own capacities to protect themselves and demand their right through knowledge and skills;

$>$ Increasing capabilities of families, caregivers, and everyone who comes to contract with children, to be able to provide effective care and protection of children;

The provision of basic service for child such as health and education as well as specific services for children who have been victims of violence, abuse, and exploitation;

Government provide to monitoring in terms of violations of children's rights and child protection system as whole.

UNICEF works with government and NGO parterres, with communities, the media, education and children themselves to build and strengthen the protective environment so that children do not get harmed and happens which support to circumstances and risks.

Since 1990 - child labor has referred to in connection with "human right" and "education" particularly after the worldwide ratification of the UN Convention on the right of the child (1989).

\subsection{Child Protection and UNICEF}

The vision of UNICEF child protection approach "Protective environment for all children" The means child working , including the Government, communities, schools, families, Panchayat member, teachers and Aganwari worker to violence, abuse, and exploitation. This protective environment, which implies the establishment of a responsive system to address violation of children's right to protection. UNICEF has some key such as

$>$ Government's duty protect to children, which reflected in a strong and sensitive policy for children.

$>$ Appropriate provision, which safeguards children's rights, and sufficient financial and human resources to implement the laws;

\subsection{Challenges of child labor}

1. - Poverty- Child labor below as poverty line. Poor families force their children to work to supplement of their families income. Poverty has direct impact on education and health of schooling children. Child labor is increasing to main cause of household poverty- low family income.

2. Illiteracy and unemployment major cause of child labor in India and state of Uttar Pradesh.

3. Challenges of qualitative education

4. Family inadequate measures of social security,

5. Low level of Parental education,

6. Poor families are discouraged from sending their children to school in instead to work.

World -wide, or an estimated 1.1 billion people, either unemployed or living in poverty (ILO-2011) Global Employment report had published.

\subsection{Vulnerable Groups of Children}

1. Children are in rural and urban area particularly where health and public service are poor. 
2. Schedule caste and Schedule Tribe caste such as belong to weaker section of society.

3. Children of migrate family's workers.

4. Street children

5. Child is domestic workers.

6. Children; who are trafficking for purpose of labor, bounded labors.

\subsection{Household Poverty}

Children work because their families are poor, and their families are lack of production assets. Such as skills, jobs, credit or land some time creates very difficulties than choice the work and starvation. When household are so poor, that is earning of a child need for survival. The quality of education will not influence decisions to keep children in work. In more extreme situation, children are forced to pay for family debt (illness, starvation,...etc). Poverty and child labor have often inter-linked the poor family younger children are more likely to work and not attend to school. Children send to school and provide qualitative education reduce the poverty, including investing in basic services, such as drinking water, and sanitation, electricity and roads and the introduction of social safety net.

\subsection{Status of Child Labour in Uttar Pradesh}

The latest available estimation from NSSO (2007-08) reveals that in India around 5 million children are economically active in the labour market, which accounts for 2 percent total population children between the age group of 5-14 years. It estimated that there are 60 to 115 million working children in India, which was highest in 1996 according to human rights. The Government of India has estimated 12.7-million child labour aged 5-14 years out of a total population of 253 million children. Children participation could be both physical as well as mental. The child has deprived and vulnerable condition, the lawmakers of the country have always accorded to privileged status to children

\section{"One in five child labour is from Uttar Prdaesh" - The Hindu}

The child labour rises in urban area: The analysis also points out to a dangerous trend child labour in urban area. When analysis; the child labour than find urban area has increased by 53 percent during 2001=2011. The children are working base 80 percent in rural area. Children are 3 out of 4 percent work in agriculture as cultivators or in household industries. The most of which are home based employment the report said- Interesting, more than half of working children in India, concentrated in in five major states namely- Uttar Pradesh 13 percent child growth with one out of five child labour in India belonging to the state, the report said. The child labour is analysis situation in Uttar Pradesh more than 21 percent of working children the country, 10 million working children below the age of 14 in India, The share of Uttar Pradesh is 2.17 million. The work contributions of children are in 5-6 age group 3 and 6 percent children the age of 14 (ILO year of 2017). In India, the number of child works has declined by more than 20 percent in the 2011 census as compared to the 2001 census. Uttar Pradesh child labour census year have been increase of 13 percent in the number of child labour in 2011 when compare to the 2001 census.

Table-5.1: Child worker in 2001 and 2011

\begin{tabular}{|c|c|c|c|}
\hline Census years & Total & Male & Female \\
\hline 2001 & $8,01,724$ & 605111 & 196613 \\
\hline 2011 & 896301 & 587508 & 308793 \\
\hline
\end{tabular}

Source: Census years 2001, 2011

The state of Uttar Pradesh is highest child work in India. According census 2011-2,176,706-child works in 2001 State while 0.8 percent population growth per annum and child worker grew 1.2 per cent per year. Although overall poverty has declined but high incidence, poverty remains concern in the Central and Eastern region of State. Incidence of child labour increase 45 districts in Uttar Pradesh and decrease only 25 districts (census 2001-2011. The many number of child is high poverty, districts were located in the central and eastern region of the state (Arora and Singh 2015: 2018). High concentration of child labour was found in Western and Central region state Uttar Pradesh, particularly in urban area, with a lower concentration in Southern and Eastern Uttar Pradesh (see appendix table 5.1A). The child worker had pushed out of region in Southern and Eastern Uttar Pradesh, which had a higher incidence of poverty, landless or marginal land holdings. Major seven districts hotspot child labour Agra, Firozabad, Bareilly, Allahabad, Varanasi and Gaziyabd. Child worker continue engaged in industry- such as footwear industry in Agra, glass industry Firozabad, the silk- wearing industry in Varanasi, Zari industry in Bareilly, the handloom carpet industry in MirzapurBhadoi (Bhadoi now known as Sant Kabir Nagar), and lock- making industry I Aligarh. Allahabad, Koshambi, Jaunpur and Sonebhadra, these are 
International Journal of Trend in Scientific Research and Development (IJTSRD) ISSN: 2456-6470

economically backward- with low income level families live the below subsistence level. Child labour generated situation- child labour very high because in brassware industry work in Muradabad.

Table-5.2: Top ten districts highest child labour in rural and urban Uttar Pradesh

\begin{tabular}{|c|c|c|c|c|}
\hline SR. & Districts & Total child labour (thousand) & Rural (thousand) & Urban (thousand) \\
\hline 1 & Allahabad & 87,237 & 65,414 & 21,823 \\
\hline 2 & Bareilly & 68,017 & 43,112 & 24,905 \\
\hline 3 & Jaunpur & 60,229 & 57,848 & 2,443 \\
\hline 4 & Gajiyabad & 56,388 & 17,041 & $\mathbf{3 9 , 3 4 7}$ \\
\hline 5 & Gonda & 55,984 & 53,456 & 2,528 \\
\hline 6 & Agra & 54,869 & 24,100 & $\mathbf{3 0 , 7 6 9}$ \\
\hline 7 & Ballia & 50,749 & 46,766 & 3,983 \\
\hline 8 & Gorakhpur & 49,787 & 40,182 & 9,605 \\
\hline 9 & Lucknow & 49,423 & 17,065 & $\mathbf{3 2 , 3 5 8}$ \\
\hline 10 & Sitapur & 48,583 & 43,693 & 4,830 \\
\hline
\end{tabular}

Source: Census-2011

Analysis the child labour in Uttar Pradesh the find to above going toward the below top 10 districts highest child labour such as districts name given the above table. If see the overall number of highest child labour in Allahabad districts than Bareilly districts comes second position. Analysis the rural and urban child labour than find the three districts Urban child labour highest in top 10 districts, such as three districts name Ghaziabad first (39,347 urban child labour), Second Luck now (32,358 urban child labour), $3^{\text {rd }}$ Agra districts.

If see the rural child labour analysis than find highest child labour in Allahabad districts ,than Bareilly district, $3^{\text {rd }}$ Jaunpur district, In top ten district lowest child in Sitapur districts. Almost all of the 10 districts within 7 districts highest rural child labour and 3 districts highest urban child labour in Uttar Pradesh districts,

Table-5.3: Top ten districts highest percentage of child labour in rural and urban Uttar Pradesh

\begin{tabular}{|c|c|c|c|c|}
\hline $\begin{array}{c}\text { SR. } \\
\text { No. }\end{array}$ & Districts & $\begin{array}{c}\text { Rural } \\
(\%)\end{array}$ & $\begin{array}{c}\text { Urban } \\
(\%)\end{array}$ & $\begin{array}{c}\text { Total } \\
(\%)\end{array}$ \\
\hline 1 & Allahabad & 5.4 & $\mathbf{7 . 7}$ & 5.9 \\
\hline 2 & Bareilly & 5.4 & $\mathbf{6 . 9}$ & 5.8 \\
\hline 3 & Jaunpur & 5.3 & 3.0 & 5.1 \\
\hline 4 & Ghaziabad & 4.6 & $\mathbf{5 . 9}$ & 5.4 \\
\hline 5 & Gonda & 6.1 & 4.9 & 6.0 \\
\hline 6 & Agra & 3.7 & $\mathbf{6 . 7}$ & 5.0 \\
\hline 7 & Ballia & 6.2 & 5.7 & 6.2 \\
\hline 8 & Gorakhpur & 4.3 & $\mathbf{5 . 7}$ & 4.5 \\
\hline 9 & Lucknow & 4.3 & $\mathbf{5 . 7}$ & 5.2 \\
\hline 10 & Sitapur & 4.1 & 3.9 & 4.1 \\
\hline
\end{tabular}

Source: Estimated Census-2011,
The child labour percentage of top 10 districts analysis the find to 6 districts maximum percentage of child labour in urban area and 4 districts rural child labour. If total percentage of child labour see than find the Allahabad first, Ballia second, Gonda third, Bareilly fourth.

\subsection{The highest child labour major state of India}

The child labour major states in India We analysis the child labour in specially Uttar Pradesh. India is about 12 state highest child labours in India. The find the highest child labour in Uttar Pradesh whole India. If compare to other state than also find to highest child in Uttar Pradesh all census years. If see the overall about $85 \%$ child labour in India works in rural area in agriculture, livestock, forestry, mining, fisheries, access to child labour include in manual base industry such as carpet, silk, bricks field, and traditional skill base training work in childhood. Thus child labour is harmful our nation, worst condition of Uttar Pradesh and Bihar.

Table-5.4: The child labour in Major state of India -Census year 1991 to 2011 (in Lakh)

\begin{tabular}{|c|c|c|c|}
\hline States & $\begin{array}{c}1991 \text { (in } \\
\text { lakh) }\end{array}$ & $\begin{array}{c}2001 \text { (in } \\
\text { lakh) }\end{array}$ & $\begin{array}{c}2011 \text { (in } \\
\text { lakh) }\end{array}$ \\
\hline $\begin{array}{c}\text { Andhra } \\
\text { Pradesh }\end{array}$ & $16,61,940$ & $13,63,339$ & $6,73,003$ \\
\hline Bihar & $9,42,245$ & $11,17,500$ & $10,88,509$ \\
\hline Gujarat & $5,23,585$ & $4,85,530$ & $4,630,77$ \\
\hline Karnataka & $9,76,247$ & $8,22,615$ & $4,21,345$ \\
\hline Kerala & 34,800 & 26,156 & 45,436 \\
\hline
\end{tabular}


International Journal of Trend in Scientific Research and Development (IJTSRD) ISSN: 2456-6470

\begin{tabular}{|c|c|c|c|}
\hline $\begin{array}{c}\text { Madhya } \\
\text { Pradesh }\end{array}$ & $13,52,563$ & $10,65,259$ & $7,00,239$ \\
\hline $\begin{array}{c}\text { Mahar- } \\
\text { ashtra }\end{array}$ & $10,68,427$ & $7,64,075$ & $7,27,932$ \\
\hline Odessa & $4,52,394$ & $3,77,594$ & $3,34,416$ \\
\hline Rajasthan & $7,74,119$ & $12,62,570$ & $8,48,386$ \\
\hline $\begin{array}{c}\text { Tamil } \\
\text { Nadu }\end{array}$ & $5,78,889$ & $4,18,801$ & $2,84,232$ \\
\hline $\begin{array}{c}\text { Uttar } \\
\text { Pradesh }\end{array}$ & $\mathbf{1 4 , 1 0 , 0 8 6}$ & $\mathbf{1 9 , 2 7 , 9 9 7}$ & $\mathbf{2 1 , 7 6 , 7 0 6}$ \\
\hline $\begin{array}{c}\text { West } \\
\text { Bengal }\end{array}$ & $7,11,691$ & $8,57,087$ & $5,50,092$ \\
\hline India & $\mathbf{1 , 1 2 , 8 5 , 3 4 9}$ & $\mathbf{1 , 2 6 , 6 6 , 3 7 7}$ & $\mathbf{1 , 0 1 , 2 8 , 6 6 3}$ \\
\hline
\end{tabular}

Source: India is Census years (1991, 2001, and 2011).

If analysis the census year to 1991 than find the highest child labour in the Andhra Pradesh highest number child labour in India, second Uttar Pradesh, third Madhya Pradesh, and Maharashtra fourth.

$>$ During the census year 2001 state of Uttar Pradesh highest number of child labour compare to major states, second Andhra Pradesh, Bihar third, and Madhya Pradesh is fourth.

The census year 2011 see the major state child worker in India then find increasing way first rank Uttar Pradesh highest child labour compare to major states, second Bihar, Rajasthan third and Maharashtra is fourth.

$>$ During the census year 1991, 2001, 2011 continuous child labour decreasing in major state states such as - Andhra Pradesh, Gujarat, Karnataka, Madhya Pradesh, Maharashtra, Odessa, Tamil Nadu.

$>$ State of Uttar Pradesh continuous child labour is increasing each census year $(1991,2001$, and 2011).

$>$ Kerala state child labour is decreasing in2001 compare to 1991, and increasing in 2011 compare to the 2001. If analysis the child labour all over the major state compare of India than find the child labour less number all census years in Kerala.

$>$ State of Bihar child labour is increasing in census year 2001 compare to 1991, and decreasing in 2011 compare the 2001.

$>$ If see the state of Rajasthan than find the child labour is increasing in census year 2001 compare to 1991 and decreasing in 2011 compare the 2001.

Thus we analysis maximum number of state child labour has been decreasing, and some state decreasing than increasing way. Because Uttar Pradesh state highest number of child labour in 2011 and continuously increasing child labour. So Uttar Pradesh worst condition child labour in India.

\section{Table-15.5: State with high incidence of child labour (Census-2011)}

\begin{tabular}{|c|c|c|}
\hline State & Percentage & $\begin{array}{c}\text { Number (in } \\
\text { Millions) }\end{array}$ \\
\hline Uttar Pradesh & 21.5 & 2.18 \\
\hline Bihar & 10.7 & 1.09 \\
\hline Rajasthan & 8.4 & 0.85 \\
\hline Maharashtra & 7.2 & 0.73 \\
\hline $\begin{array}{c}\text { Madhya } \\
\text { Pradesh }\end{array}$ & 6.9 & 0.70 \\
\hline
\end{tabular}

Source: Census-2011

Analysis the census year 2011 than find highest percentage of state of Uttar Pradesh and number of child labour is above the two million cross. If see the Bihar state second stage of child labour percentage in census year 2011 and number of child is above the one million cross. Thus third Rajasthan, fourth Maharashtra, fifth Madhya Pradesh.

Table-15.6: Percentage of child labour in social groups (\%) in BIMARU states of India

\begin{tabular}{|l|l|l|l|l|}
\hline State & SCs & STs & Others & Total \\
\hline Bihar & 4.3 & 6.1 & 3.6 & 3.8 \\
\hline Madhya Pradesh & 3.4 & 7.3 & 3.1 & 4.2 \\
\hline Rajasthan & $\mathbf{5 . 3}$ & $\mathbf{7 . 6}$ & $\mathbf{4 . 6}$ & $\mathbf{5 . 2}$ \\
\hline Uttar Pradesh & 4.3 & 5.3 & 4.3 & 4.3 \\
\hline
\end{tabular}

Source: census 2001 and 2011

Analysis the percentage of child labour in social groups than find total number highest in Rajasthan and social groups STs highest child worker and second Madhya Pradesh, compare to other social groups than comes SCs, Others also.

Bihar and Uttar Pradesh are also highest child labour in STs Community than second SCs come both states equal percentage but STs highest compare to Uttar Pradesh. 
International Journal of Trend in Scientific Research and Development (IJTSRD) ISSN: 2456-6470

Table-15.7: The percentage of sector wise distribution of child labour in BIMARU states (2009-10) \begin{tabular}{l|c|c|c|c|c|c|c|} 
States & Agriculture & Mining & Manufacturing & Construction & Trade/Hotel & Transport & Others \\
\hline
\end{tabular}

\begin{tabular}{|c|c|c|c|c|c|c|c|}
\hline Bihar & 67.32 & 0 & 10.45 & 2.1 & $\mathbf{1 4 . 9}$ & 0.04 & 5.6 \\
\hline $\begin{array}{c}\text { Madhya } \\
\text { Pradesh }\end{array}$ & $\mathbf{7 9 . 2 1}$ & 0 & 10.1 & 2.5 & 6.3 & 0.0 & 1.9 \\
\hline Rajasthan & 73.4 & 0 & 10.5 & $\mathbf{3 . 6}$ & 8.1 & 1.1 & 2.9 \\
\hline $\begin{array}{c}\text { Uttar } \\
\text { Pradesh }\end{array}$ & 57.8 & 0 & $\mathbf{2 2 . 3}$ & 3.2 & $\mathbf{1 1 . 4}$ & 1.1 & 4.2 \\
\hline
\end{tabular}

Source: Estimated units level records of NSSO, 2009-10

If we see the sector wise contribution of child labour BIMARU state than find agriculture sector highest child labour all over high each state compare to other sector, but in agriculture highest child labour in Madhya Pradesh.

In manufacturing sector highest is child, labour in Uttar Pradesh than comes Bihar second. In construction sector Rajasthan is come first compare to BIMARU state the second comes state of Uttar Pradesh. Bihar comes in first child labour in trade/hotel sector second state of Uttar Pradesh. If the transport sector than find nominal percentage of child labour in Bihar and Madhya Pradesh and Uttar Pradesh and Rajasthan equal percentage above one percent. In other sector, Bihar is first and Uttar Pradesh second contribution of child labour.

Table-15.8: Sector wise distribution child labour in India during the 2009-10 (In percentage

\begin{tabular}{|l|l|}
\hline Sector & Year (2009-10) \\
\hline Agriculture & 68.14 \\
\hline Manufacturing & 16.55 \\
\hline Trade and hotel & 8.45 \\
\hline Communities and social service & 3.41 \\
\hline Construction & 1.95 \\
\hline Others & 1.50 \\
\hline Total percentage & 100.00 \\
\hline
\end{tabular}

Source: NSSO $60^{\text {th }}$ round estimated,

If the see the all over India contribution child labour than find agriculture sector highest percentage of child labour in India and second position manufacturing. Thus, worst condition is child labour in agriculture sector.

\subsection{Child labour sees the Global Scenario}

Child labour issues of world level, especially in developing countries Africa and together account $90 \%$ of total child employment. Child labour is a crime committed against out of every seven children in the world. According International Labour Organization report 250 million child worked aged 5-14 were involved out of which 171 million's hazard work. The ILO reports say that largest number of child labour was seen in south Asia. The most rapidly and widely ratified international human rights treaty in the history has been, signed by 193 countries world- wide by United Nation convention on the right of the child and widely (UNCRC). India's has worst condition of child labour in the world. India's has comparative analysis of child labour in south Asia.

Table-5.9: The children and working children (age groups 5-14 years) in South Asian countries (in millions)

\begin{tabular}{|c|c|c|c|}
\hline Countries & $\begin{array}{c}\text { Working } \\
\text { children }\end{array}$ & $\begin{array}{c}\text { Total } \\
\text { Number } \\
\text { of } \\
\text { children }\end{array}$ & $\begin{array}{c}\text { Working } \\
\text { children as } \\
\text { the total } \\
\text { number of } \\
\text { children }\end{array}$ \\
\hline Bangladesh & $\begin{array}{c}5.05 \\
(21.88)\end{array}$ & $\begin{array}{c}35.06 \\
(10.39)\end{array}$ & $14.40 \%$ \\
\hline India & $\begin{array}{c}\mathbf{1 2 . 6} \\
(\mathbf{5 4 . 5 9 )}\end{array}$ & $\begin{array}{c}\mathbf{2 5 3 . 2 2} \\
\mathbf{( 7 4 . 9 7 )}\end{array}$ & $4.98 \%$ \\
\hline Nepal & $\begin{array}{c}1.66 \\
(\mathbf{7 . 1 9})\end{array}$ & $\begin{array}{c}6.22 \\
(1.84)\end{array}$ & $\mathbf{2 6 . 6 8 \%}$ \\
\hline Sri Lanka & $\begin{array}{c}\mathbf{0 . 4 7} \\
\mathbf{( 2 . 0 4 )}\end{array}$ & $\begin{array}{c}3.18 \\
(0.94)\end{array}$ & $8.25 \%$ \\
\hline Total & 23.08 & 337.46 & $6.84 \%$ \\
\hline
\end{tabular}

Source: ILO (2009) child labour and response in South Asia,

(Note- figure in brackets are percentage of total)

Analysis the child labour in south Asian countries than find highest working child labour in India, and working children as the total number of children percentage less compare to all south Asian countries.

$>$ Lowest working-children in Sri Lanka and highest percentage are working children as the total number of children in the Nepal.

South Asian countries total working number is 23.08 millions. 


\subsection{Child labor access to education}

During the globalization of Indian economy, the poor household could not find better alternative source of income except to work. Child labour has directed relation to poverty, education, about employment, human development and overall development of society. The child labour is usually define as particular of children between 4-14 year in gainful activity. India has largest population of child labour which constitution nearly seven percent of the work force. Child labour restricts the right of children to access and benefit from education and denies the fundamental opportunity to attend school. The child labour pre juices children's education and adversely affects their health. Status of child labour could be expected barrier to their primary education, poor standard of living and other evils of society. Social and cultural deprivations are responsible factor of child labour. The lack of exposure-is access to education lead to level of literacy among people belonging to schedule caste and schedule tribes. The parents believe that working children will be equipped with many skills for the future.

\section{Quality of education child labour:}

For the International Trade Union Confederation and the Global Union Federation, school is the only legitimate workplace for children. The ITUC is working with Education International (EI) to promote free, compulsory, quality education for all, through education systems financed and regulated by the public authorities. Child labour is about the exploitation of the most vulnerable, disadvantaged and marginalized in society. The child labour is work, which contravenes national and international standards concerning the work of children. The link between the child labour and education have little alternative but to enter the labour market, where they are forced to work in dangerous and exploitative conditions. Expenditure on access to education is free and compulsory. It is crucial to reducing child labour, as the provision of quality education. Access to education is necessary but it is not sufficient without qualitative education. Only quality education can ensure that children have enrolled and stay in school. The curriculum must be relevant and the school a safe and welcoming environment for learning for both boys and girls. Children who receive an education of quality are more empowered to escape likely to send their children to school. Millennium Development Goals are the Education for all framework for action, free, compulsory, quality education for all. A vital contribution is the work to end child labour and provide education for all. National and international agenda achieving the goal the every child benefits from the education. Which are giving to their right?

UN convention on the rights of child-(18 year age)- child labour.

ILO convention 138 (14 or 15 year age)- child labour.

The work economic activities-which is likely to harm the health, safety or moral of children (often referred to as hazardous work).

"Universal access to free, compulsory, quality of basic education is the foundation for the effective elimination of all child labour'. The correlation is between progress and reducing child labour and reaching education for all.

Prof. Amartya Sen- recently emphasized that education as an important parameter for any inclusive growth in an economy.

In Indian context - The Right of Children Free and Compulsory Education (RTE) Act came into force in 2010, which provides the right of children free and compulsory education. The provisions relating to school infrastructure and Pupil Teachers Ratio (PTR), training to untrained teachers, Quality interventions are prescribing under the act. The Sarva Shiksha Abhiyan Scheme (SSA) aims to provide free and compulsory elementary education to all children.

\subsection{Education status}

Table-5.10A: Status of education

\begin{tabular}{|c|c|c|c|c|c|c|c|}
\hline \multicolumn{4}{|c|}{ Primary } & \multicolumn{4}{c|}{ Upper Primary } \\
\hline State/Country & Year & $\begin{array}{c}\text { Gross } \\
\text { Enrollment } \\
\text { Ratio }\end{array}$ & $\begin{array}{c}\text { Net Enrollment } \\
\text { Ratio }\end{array}$ & $\begin{array}{c}\text { Average } \\
\text { Dropout } \\
\text { Rate }\end{array}$ & $\begin{array}{c}\text { Gross } \\
\text { Enrollment } \\
\text { ratio }\end{array}$ & $\begin{array}{c}\text { Net } \\
\text { Enrollment } \\
\text { Ratio }\end{array}$ & $\begin{array}{c}\text { Average } \\
\text { Dropout } \\
\text { Rate }\end{array}$ \\
\hline Uttar Pradesh & $2010-11$ & 105.17 & 94.18 & 11.85 & 59.59 & 47.13 & 3.97 \\
\hline India & $2010-11$ & 118.62 & 99.89 & 6.5 & 81.15 & 61.82 & 6.56 \\
\hline
\end{tabular}

Source: Status of education in Uttar Pradesh, DISE-2011-12, 
Table- 5.10B

\begin{tabular}{|c|c|c|}
\hline $\begin{array}{c}\text { Uttar } \\
\text { Pradesh }\end{array}$ & $\begin{array}{c}\text { Average Retention at } \\
\text { Primary level in schools }\end{array}$ & 80.39 \\
\hline India & // & 75.94 \\
\hline
\end{tabular}

Source: DISE-2011-12

The status of children's education primary and upper primary state of Uttar Pradesh and India's comparative analysis then find that Uttar Pradeshgross enrollment ratio less compare to India both primary and upper primary school. if see the net enrollment high primary level in Uttar Pradesh and less Upper primary level compare to India. Average dropout high primary level in Uttar Pradesh and Upper Primary less compare to India. If see the table 5.9B than find average retention primary school high compare to India. Thus, Uttar Pradesh Government, Lunch the "Naya Savera" technical support of UNICEF for child labour free village is selected child labour prone districts. Lunched of on 12 Jun 2017 has a Anti - Child Labour Day. Objective to ensure enrollment and retention of the working children identified in the selected child labour prone villages. (Uttar Pradesh Government-target for 2017-18: that is achieving the 125 villages to be declared child labour free villages).

\subsection{Pupil-Teacher Ratio}

Uttar Pradesh has India's largest population of Children but least teacher per student.

Table-5.11: Pupil - Teacher Ratio by level: 2014-15 and 2015-16 in BIMARU States

\begin{tabular}{|c|c|c|c|c|}
\hline \multicolumn{3}{|c|}{ Primary } & \multicolumn{2}{c|}{$\begin{array}{c}\text { Upper } \\
\text { Primary }\end{array}$} \\
\hline State/country & $2014-15$ & $\begin{array}{c}2015- \\
16\end{array}$ & $\begin{array}{c}2014- \\
15\end{array}$ & $\begin{array}{c}2015- \\
16\end{array}$ \\
\hline Bihar & 35 & 36 & 23 & 24 \\
\hline $\begin{array}{c}\text { Madhya } \\
\text { Pradesh }\end{array}$ & 22 & 22 & 19 & 18 \\
\hline Rajasthan & 17 & 17 & 10 & 10 \\
\hline Uttar Pradesh & $\mathbf{3 9}$ & $\mathbf{3 9}$ & $\mathbf{3 3}$ & $\mathbf{3 1}$ \\
\hline All India & 24 & 23 & 17 & 17 \\
\hline
\end{tabular}

Source: DISE-2015-16, Ministry of HRD, GOI Department of Education Literacy.

Analysis the pupil-teacher ratio in Uttar Pradesh state worst condition primary and upper primary school, because compare to BIMARU states and national average then find highest Pupil-teacher ratio per student in Uttar Pradesh state second comes Bihar states.

Thus out-of-school children are child labour is not convincing because, among other reasons, it sounds as if work and schooling are mutually, exclusive activities for children, referring to than as educationally deprived children is justified for the prospective of human capital, development and human rights. The $21^{\text {st }}$ century starts with vast asymmetries for children in term of income access to food, water, health, education, housing, or employment for their families, half of the world's children are below the poverty line of $\$ 2$ a day and suffer from multiple deprivation and violations to basic human rights (UNICEF- child poverty and inequality 2012).

State of Uttar Pradesh worst condition of qualitative education according the survey ASER if see the 2005, 2012, 2015 reports. Recently see the report Annual Education Survey report 2017 also shows the worst condition of all school level education.

\subsection{Equal Opportunity and Development}

International Labour Organization - involves opportunities for work that is productive and delivers a fair income, security in the work place and social protection for families, better prospects for personal development and social integration, freedom for people to organize and participate in the decisions that affects their lives, and equality of opportunity and treatment for all women and men.

The elimination of child labour - ILO decent work agenda that focuses on four strategic pillars such as

1. Employment

2. Rights at work

3. Social protection and

4. Social dialogue,

Indian constitution - Right to equal protection of laws (comes under the right to equality)-Its means similar treatment in similar circumstances. It is proportional equality.

\section{Article 15:}

Religion, race, caste, sex, place of birth, public place use not deprive.

However, exception- women, children, Schedule Caste/ Schedule Tribe, OBCs are deprived. 
Article-51K:

Right to Education- it is fundamental duty of guardian/parent to send their children between the age of 6-14 send to school.

\subsection{Conclusion}

Child labour is as work by deprived children of their childhood and their dignity hampers, their development need to access education. Child labour descriptive analysis based on secondary data baseNSSO, Census, UNICEF, ILO etc. If See child labour the historical background than child labour also find in Ancient, Medieval, and Modern period. The child labour protect by the Indian constitution, ILO and UNICEF. These institutions support to education development and prohibited to child work provision to Laws. Right to education support to child enrollment is increasing in school free and compulsory education for child development. Child labour is increasing because their family too poor and their earning of income source are not sufficient. So poor families are force to pay debit or live to sustain life child labour for income. The child labour is highest in Uttar Pradesh. One-in five-child labour is from Uttar Pradesh. Find the top ten districts of child labour in Uttar Pradesh. Thus four districts rural child labour is highest such as Jaunpur, Gonda, Ballia, Sitapur, and in urban area districts - Allahabad, Bareilly, Ghaziabad, Agra, Gorakhpur, Lucknow. Chronological order to ten districts are all over highest child labour such as-Allahabad, Bareilly, Jaounpur, Ghaziabad, Gonda, Agra, Ballia, Gorakhpur, Lucknow, Sitapur. Uttar Pradesh is highest child labour analysis the major states. Analysis the census year 1991, 2001, 2011 than find continuously number of child is increasing in Uttar Pradesh. In BIMARU, state highest child labour in STs Community than SC groups come census year 2011. All over highest percentage of child labour in agriculture sector is first, second number manufacturing sector and third trade/hotel. If analysis the Global prospective child labour in South Asia than find highest child labour working child labour and total number of child labour in India. If see the total number of child labour high percentage in Nepal. Education status in Uttar Pradesh- Gross enrollment ratio less compare to national average and dropout children need to reach zero level. Uttar Pradesh state's - pupil teacher ratio is lowest compare to BIMARU. Access to education with quality each child, but Uttar Pradesh is the worst condition according to ASER, National Achievement Survey 2017 reports. Lack of opportunity is deprivation in weaker section of society. So need to strongly protest and development the child labour of weaker section of society. Thus, National and International agenda achieving the goal every child benefit to education with quality. Prone area-child labour has been need to increasing enrollment ratio and provide to better qualitative education. Thus identified significant area need to reduce child make the plan strategy by the Government.

\section{References}

\section{Book:}

1. India Labour year Book-2011 and 2012; (Government of India-Ministry of Labour and Employment Labour Bureau, Shimila/Chandigarh,

2. Jean Dreze and Amartya Sen, "India Economic development and social opportunity (Oxford University press-1996),

3. Tripathy, S. K 1996, "Child Labour; An Introspection in Child labour in India- Issues and Policy options (Ed) Discover Publishing House,

4. UNICEF (1997): Focus On Child Labour; The State of the World's Children, New York: Oxford University Press,

\section{Journals:}

1. A-Bequele and J Boyden (Eds) 1988: "Combating Children Labours (Geneva: ILO),

2. Base, K. Van, P.(1998), "The Economic of Child Labour (American Economic Review, 88 (3) 41227 ,

3. Christian Grootaert and Ravi Kanbur (1995); Child labour; A Review (The World Bank, December 1994, pp-2-35),

4. Myron Weiner: "Child labour in India, (Economic Political Weekly, November 9-16, 1996, pp30073014),

5. M. Venkatnarayana (2004); Out-of-School; Child Labours or Educationally Deprive,

6. Swarnlata, K. Anuradha RK, "Causes and Consequences of Child Labour Government Initiatives, (International Journal of Home Science 2016;2 (1):

7. Zubeda Bashir, "Child labour in India: Cause and Intervention, (International Journal of Scientific Research and Education, Vol.2, October 2014, ISSN (e) 2321-7445, 
International Journal of Trend in Scientific Research and Development (IJTSRD) ISSN: 2456-6470

Working Papers/Reports/Conferences:

1. Cambridge University- Marshall Lectures: "Development and Transition idea Strategy and Viability, By Justin Yiful Lin on October 31November, 2007,

2. Combating Child Labour thought Education; A Summary of a project knowledge sharing workshop Turin, 8-12, April 2013 (International Program on the elimination of child labour-IPEC)

3. Education for all Global Monitoring Report-2007, UNICEF,

4. Ganesh Kumar: Child labour determinants, Dimensions and polices in India, (Economic Affairs: 58 (4) 417- December, 2013),
5. Child labour in Uttar Pradesh; Situation Analysis (Census 2011),

6. ILO: Constitution of the International Labour organization and selected texts (Geneva, 2010) www.ilo.org/public/english/bureau/leg/downward/ constitution, pdf,

7. State of Child labour working in India- Mapping trends- UNICEF- for every child (V.V.GIRI, National Labour Institution, 2011, census data use),

8. The Hindu, "One in five child labour in from Uttar Pradesh, May 7, 2017,

9. UNICEF- Child poverty and Inequality-2012, 